\author{
Sergei BOSIAKOV ${ }^{1}$ \\ Anastasiya VINAKURAVA ${ }^{2}$ \\ Iryna SLAVASHEVICH ${ }^{3}$ \\ Dmitri GRICHANYUK ${ }^{4}$ \\ Feliks STACHOWICZ ${ }^{5}$
}

\title{
EFFECT OF HYRAX SCREW LOCALIZATION ON CRANIUM RESPONSE DURING RAPID MAXILLARY EXPANSION
}

\begin{abstract}
Rapid maxillary expansion is employed for the treatment of cross-bite and deficiency of transversal dimension of the maxilla in patients with and without cleft of palate and lip. The aim of this study is the finite-element analysis of stresses and displacements of skull, with and without unilateral cleft, after application of the HYRAX orthodontic device. Three different constructions of the orthodontic Hyrax device with different positions of the screw - in the occlusal horizontal plane, near occlusal horizontal plane and near the palate - are considered. Application of the orthodontic device corresponds to the rotation of the screw on one-quarter turn. It is established that the screw position significantly affects the stress patterns in skull and displacements of the cranium with and without unilateral palate cleft. Depending on the construction of the orthodontic appliance, the maxilla halves in the transversal plane are unfolded or the whole skull is entirely rotated in the sagittal plane. The obtained results can be used for designing of orthodontic appliances with the Hyrax screw, as well as for planning of osteotomies during the surgical assistance of the rapid maxillary expansion.
\end{abstract}

Keywords: rapid maxillary expansion, intact skull, palate cleft, finite element method, HYRAX device, stress-strain state

\section{Introduction}

Rapid maxillary expansion is one of the various treatments for the narrow transverse dimension of the maxilla. The rapid expansion of the maxilla is rec-

\footnotetext{
${ }^{1}$ Author for correspondence/autor do korespondencji: Sergei Bosiakov, Belarusian State University, 4 Nezavisimosti avenue, 220030 Minsk, Belarus, tel. +375172095345 , e-mail: bosiakov@bsu.by

2 Anastasiya Vinokurova, Rzeszow University of Technology, e-mail: vinakurava@prz.edu.pl

3 Iryna Slavashevich, Belarusian State University, e-mail: slavashevichi@yandex.ru

${ }^{4}$ Dmitri Grichnyuk, Belarusian Medical Academy of Postgraduate Education, e-mail: dr_gda@mail.ru

${ }^{5}$ Feliks Stachowicz, Rzeszow University of Technology, e-mail: stafel@ prz.edu.pl
} 
ommended by using fixed devices, in particular, Hyrax or palatially distractors to separate parts of the maxilla by opening the mid palatal suture $[4,8,19]$. The most hygienic devices among the various types of orthodontic appliances are with a Hyrax screw. Furthermore, devices of this type are the least traumatic and more comfortable for the patient, and also they have a low percentage of complications after application. At the same time, the design features of devices for maxillary expansion affect the intensity and nature of displacement of bone structures of the skull and teeth $[11,20]$.

Generally, to understand the influence of maxillary dilatation on the bone structures of the skull and teeth the finite element modeling is used $[6,10,12$, $13,14,17,18,22]$. An extensive review of the computational calculations of stresses and displacements of the maxillary complex when exposed to different types of orthodontic appliances was done in one of the previous works [15]. Common simplifying assumption adopted in the above-mentioned works and other similar finite element studies is the simulation of action orthodontic appliance on the bone structures of the skull through the application of transversal displacements or forces to certain teeth. In particular, to simulate the clinical situation, ere applied displacements of $5 \mathrm{~mm}$ were applied in a transversal plane to the upper premolars and first molars [17]. In [22] it is assumed that the orthodontic device is absolutely rigid. Therefore, for modeling the clinical situation in [22], certain displacements were applied corresponding to a specific number of revolutions of screw of the machine. The authors emphasize that the same simplifying assumptions are made in other known studies, see [12, 13, 18].

The goal of this study is the comparative analysis of stresses and displacements of bone structures of the skull, with and without palate cleft after application of different designs of orthodontic Hyrax device. Designs of orthodontic device differ in the arrangement of the screw relative to the palate. Therefore, another goal is to evaluate the influence of the location of the Hyrax screw on the distribution and magnitudes of stresses and displacements in the maxillary complex. Finite element method is used to achieve these goals.

\section{Finite-Element Modelling}

Development of the finite element models of the skull, orthodontic appliance and the abutment teeth is described in [2, 3]. Evaluation of the stress-strain state of the maxillary complex was carried out for three designs of orthodontic appliance: design with an arrangement of rods and screw in the same horizontal (occlusal) plane (Model 1) and, designs with a screw displaced to the palate relatively to the horizontal plane of $2 \mathrm{~mm}$ and $8 \mathrm{~mm}$ (Model 2 and Model 3, respectively). The geometrical dimensions of orthodontic appliances are the same, except for the lengths of the rods which are connecting the screw of appliances with premolars and the screw with the molars. Periodontal liagament wasn't considered, because after application of the orthodontic appliance the abutment 
teeth completely cover the periodontal crevice [22]. The models of the orthodontic appliance are set up on the skull with one-side cleft or without cleft. The palate cleft is transparent and placed on the level of the second incisor on the left. The number of the elements and nodes in the calculation models of the skulls, abutment teeth and orthodontic appliances are shown in Table 1. Moduli of elasticity for the bones of the maxillary complex, orthodontic appliance and abutment teeth are shown in Table 2. Poisson's ratio for all the materials are equal to 0.3 [21]. The loading of the skull was carried out by a transversal movement of each plate on $0.2 \mathrm{~mm}$ (corresponds to a quarter turn of the screw of the orthodontic appliance $[4,7,9])$. Fastening of the skull was carried out in the nodes located near the occipital foramen $[12,13,18]$.

Table 1. Parameters of finite-element models

\begin{tabular}{|l|l|l|}
\hline Model & Number of nodes & Number of elements \\
\hline Skull without palate cleft & 77036 & 185302 \\
\hline Skull withunilateral palate cleft & 24556 & 85087 \\
\hline Model 1 & 15918 & 7798 \\
\hline Model 2 & 16410 & 8022 \\
\hline Model 3 & 19853 & 9974 \\
\hline
\end{tabular}

Table 2. Modulus of elasticity [21]

\begin{tabular}{|l|l|l|l|l|}
\hline Materials & Steel & Compact bone & Trabecular bone & Tooth \\
\hline Elasticity modulus, GPa & 200.0 & 13.7 & 8.0 & 20.7 \\
\hline
\end{tabular}

\section{Craniofacial Complex without Palate Cleft}

From the stress distributions shown in figure 1, it is seen that the stresses after application of Model 1 occur mainly in the region of upper jaw. Sufficiently high stresses are observed in the middle and lower part of the nasal passage, and also in the lower region of the left eye-socket. It can be concluded that even a slight displacement of the screw of the device from the occlusal plane to the palate leads to a redistribution of stresses in the base of the skull from the palatal part of the upper jaw to the occipital bone and the occipital foramen through the pharyngeal tubercle (Fig. 2). After application of Model 2, the stress state from the pharyngeal tubercle extends to the sphenoid bone, in particular to the lateral and medial pterygoid plates (Fig. 2) and shows that sufficiently high stresses occur in the alveolar and frontal processes of the upper jaw, in region of pharyngeal tubercle and the occipital bone. 


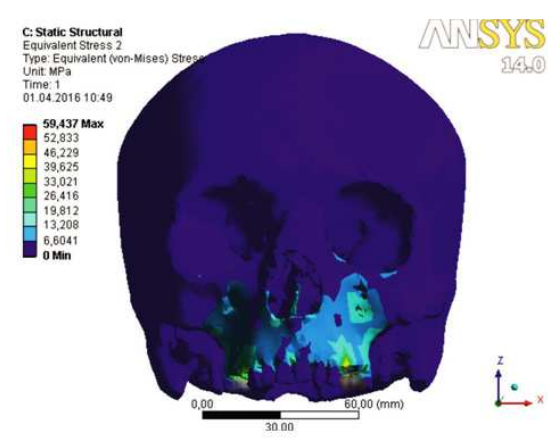

a)

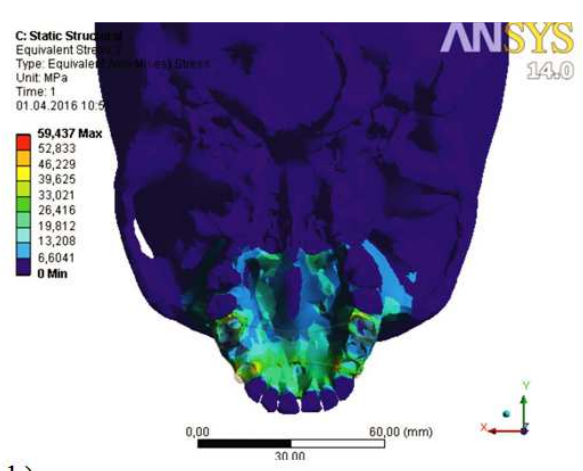

b)

Fig. 1. Stress patterns (MPa) in cranium without palate cleft after application of Model 1: pattern in front of skull (a), pattern in base of skull (b)

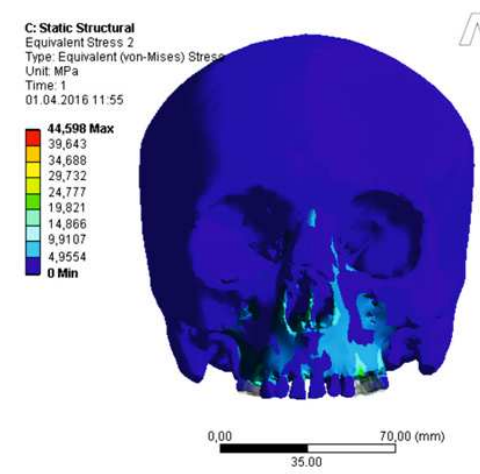

a)

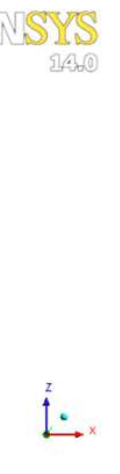

b)

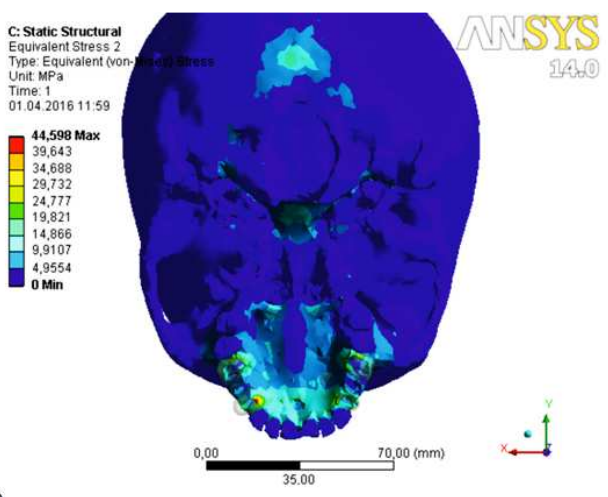

Fig. 2. Stress patterns (MPa) in cranium without palate cleft after application of Model 2: pattern in front of skull (a), pattern in base of skull (b)

From figure 3, it can be seen that after application of Model 3 the upper jaw is loaded in certain areas, and stresses are decreased. In facial part of the skull the stress region shifts from the upper jaw to the nasal aperture and to the zygomatic processes. Stresses are practically absent in the base of the skull in the region of the median palatal suture, and remain only in the region of the intermaxillary bone. At the same time, stresses occur in the occipital and the sphenoid bone in the region of occipital foramen. The stresses are practically absent in the region of the median palatal suture. Stresses in the upper jaw appear fragmentary, and the most significant stresses are observed on the lateral sides of the upper jaw. Stresses are absent in the facial part of the upper jaw, and stress region is almost completely transferred to nasal aperture. It can also be noted that, stresses increase in the sphenoid and occipital bones in the skull base. 


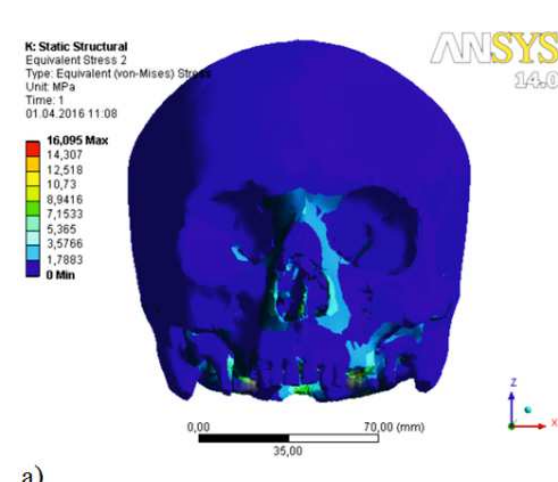

a)

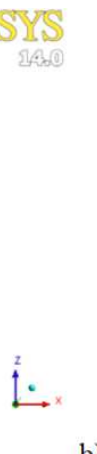

b)

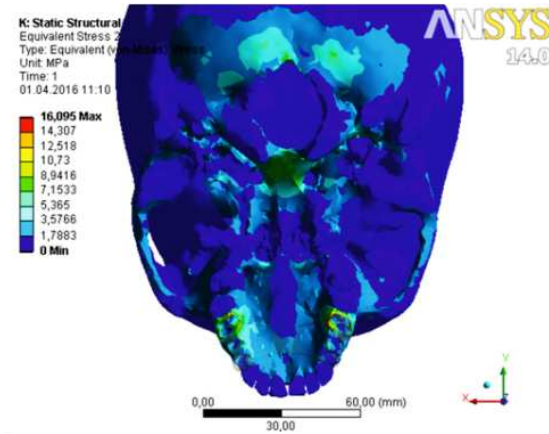

Fig. 3. Stress patterns (MPa) in cranium without palate cleft after application of Model 3: pattern in front of skull (a), pattern in base of skull (b)

From the results obtained it can be noted that after application of Model 2 (Fig. 4b), maximum displacements of points on the skull are highter than in the case of Models 1 (Fig. 4a) and 3 (Fig. 4c). Calculation of the displacements of points on the skull without cleft for intermediate positions of the screw of the orthodontic appliance (between positions corresponding to Models 1 and 3) shows that even with a slight displacement of the screw of the orthodontic appliance from the occlusal plane to the palate, displacements of points on the skull increase and reach maximum values when the location of the screw of the appliance is approximately at a distance of $0.25 \mathrm{~mm}$ from the occlusal plane. Upon the displacement of the screw of the orthodontic appliance to the palate, the maximum displacements of the points on the skull decrease to values corresponding to Model 3 (Fig. 4). At the same time, when using Model 2 the maximum transversal displacements significantly exceed (more than twice) the transversal displacements when using Model 3 (Fig. 4b). The vector fields of displacements (Fig. 4b and 4c) show that after application of Models 2 and 3 the skull is rotated counterclockwise (when viewed from the positive direction of the $x$-axis).

\section{Craniofacial Complex with Palate Cleft}

From figure 5 it can be noted that after application of Model 1, high stresses occur in the maxilla, the zygomatic process of the maxilla, nasal cavity, as well as in the regions of the maxillary and the zygomatic bones, located next to the eye-sockets. Area of stresses extends into the frontal process of maxilla, located on the same side of the skull as a palate cleft. Furthermore, stresses noticeable in nasal bone and the fronto-nasal, internasale and naso-maxillary sutures. In the skull base, the region of the high stresses is distributed through the lateral and medial pterygoid laminas to the pharyngeal tubercle. It should be noted that stresses also occur in the area covering the sulcus of the auditory 
tube. This indicates that maxillary expansion can have an impact on the enlargement of the nasal cavity and improvement of nasal breathing $[1,5,13,14$, 17], as well as change in hearing in patients with palate cleft. Note that shortterm and long-term effects of maxillary expansion on the auditory conduction is described in [16].

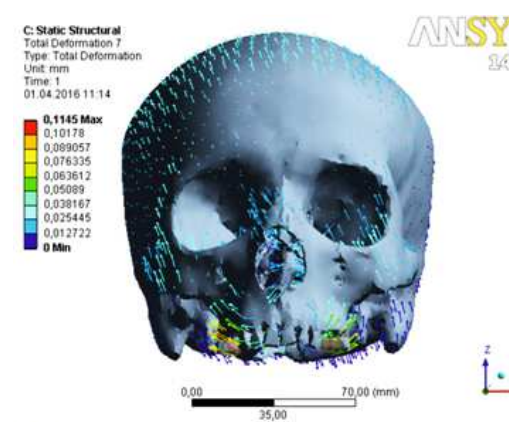

a)

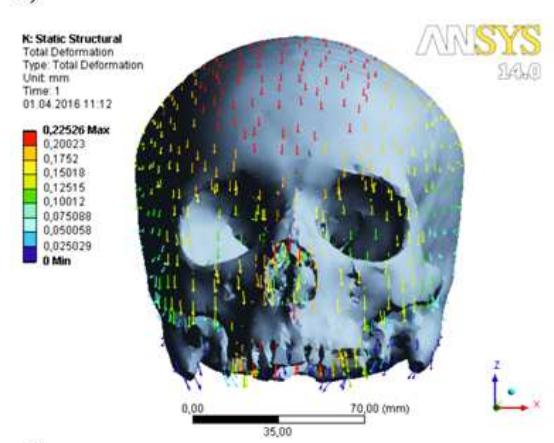

b)

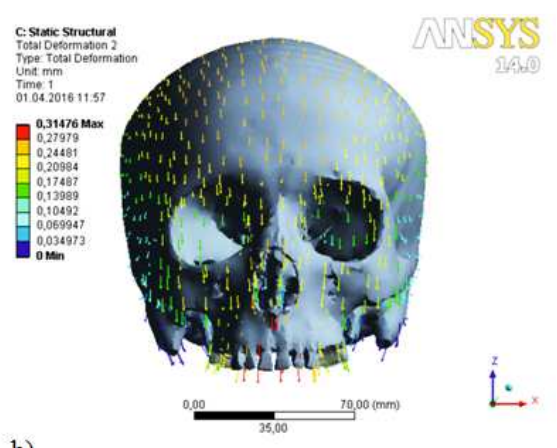

c)

Fig. 4. Vector fields of total displacements for skull without palate cleft after application of: Model 1 (a), Model 2 (b) and Model 3 (c)

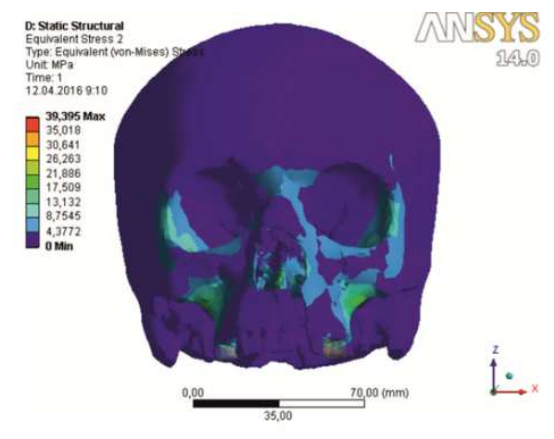

a)

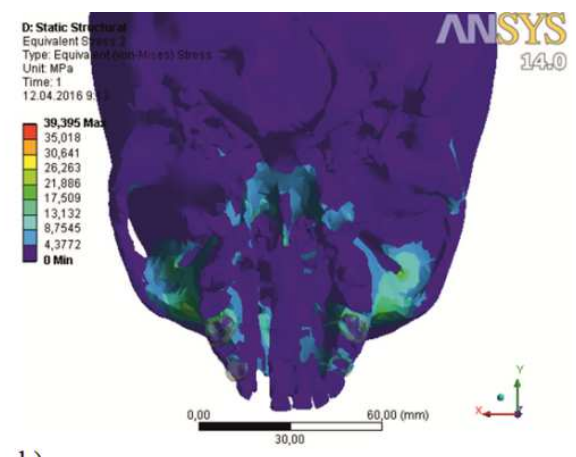

b)

Fig. 5. Stress patterns (MPa) in cranium with unilateral palate cleft after application of Model 1: pattern in front of skull (a), pattern in base of skull (b) 


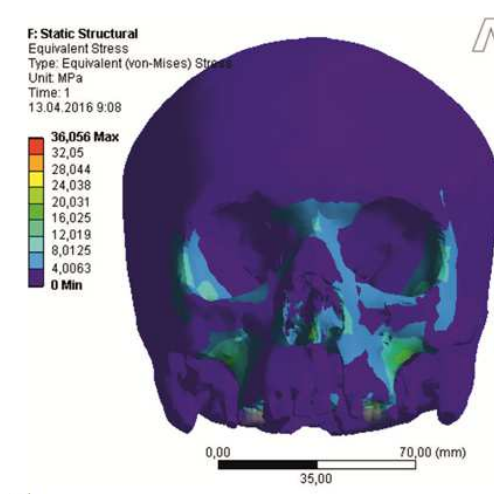

a)
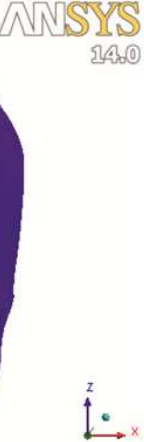

b)

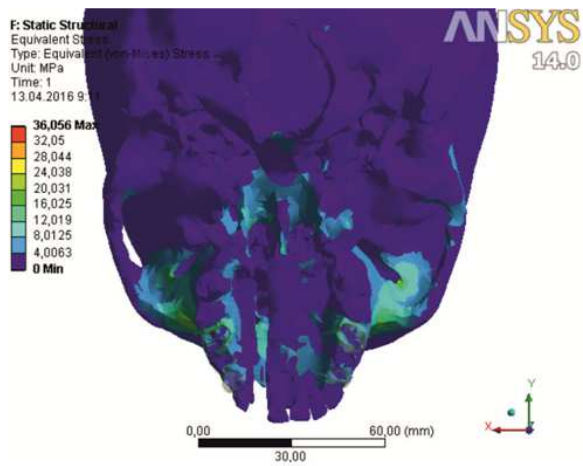

Fig. 6. Stress patterns (MPa) in cranium with unilateral palate cleft after application of Model 2: pattern in front of skull (a), pattern in base of skull (b)

From figures $5-7$, it is seen that the difference between the stress distributions are mainly in the values of the stresses. Stresses in the region of the infraorbital foramen, zygomatic and frontal processes of the maxilla and of the zygomatic bone decrease after application of Models 2 and 3 as compared to Model 1. Stresses almost disappear in the region of the zygomatic bone and infraorbital foramen after application of Model 3 (Fig. 7). At the same time, it is seen that the region of the stresses in the zygomatic and frontal processes of the maxilla remains practically unchanged. Stress state remains practically unchanged in the base of the skull after application of Models 1-3 (Fig. 5-7). Vector fields of full displacements arising in the skull with unilateral cleft after application of Models $1 \div 3$ are shown in figure 8 .

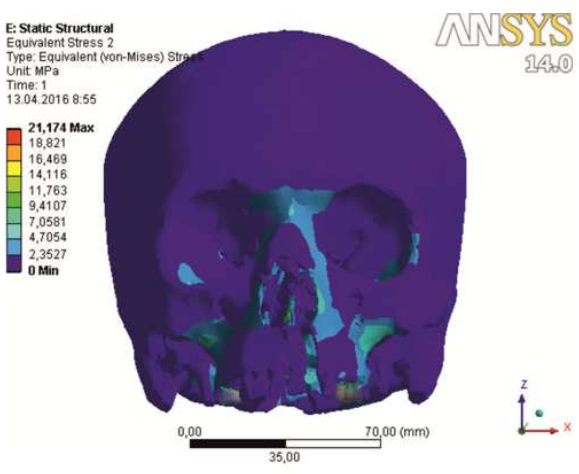

a)

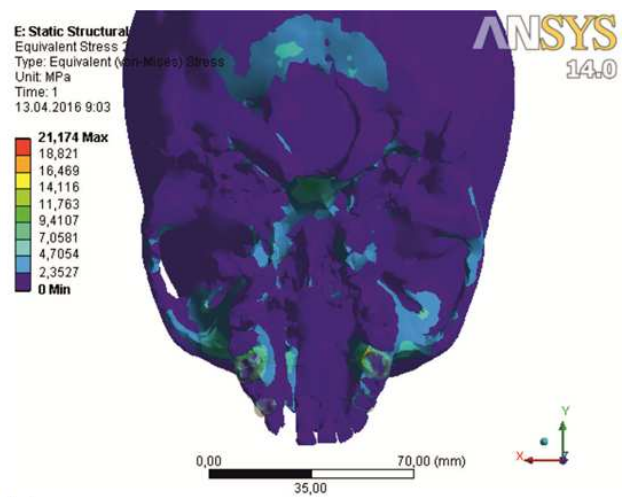

b)

Fig. 7. Stress patterns $(\mathrm{MPa})$ in cranium with unilateral palate cleft after application of Model 3: pattern in front of skull (a), pattern in base of skull (b) 
Upon the application of Model 1, there is rotation of two parts of the upper jaw relative to the horizontal axis (extending along $y$-axis), located approximately in the region of the nasal aperture. The largest are the components of the total displacement directed along the $x$-axis, i.e. transverse displacements (Fig. 8a). At the same time, the transversal displacements is comparable to the vertical component of the complete displacement, directed along the $z$-axis (Fig. 8a). The component of the vector of the total displacements of the upper jaw, collinear to $z$-axis (the $z$-axis), for the most parts of the maxillary complex is directed along the positive direction of this axis, and in the region of the front incisors and the nasal aperture is directed in the opposite direction. The smallest among the components of the total displacement is a sagittal displacement along the $y$ axis (Fig. 8a). The upper part of the skull and the region of the front jaw in the horizontal direction move backward while the rest of the upper jaw and the zygomatic arch slightly move forward.

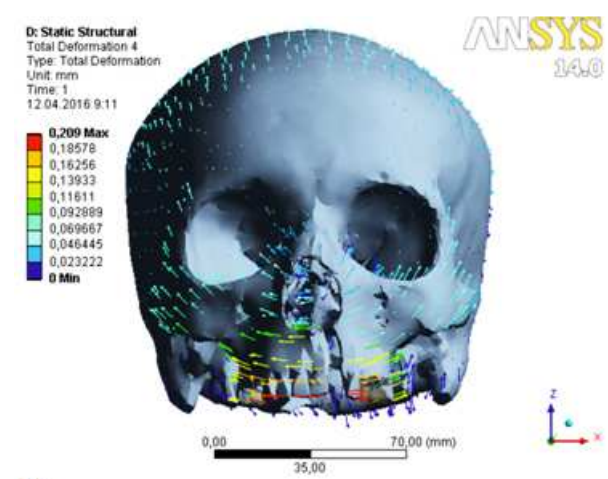

a)
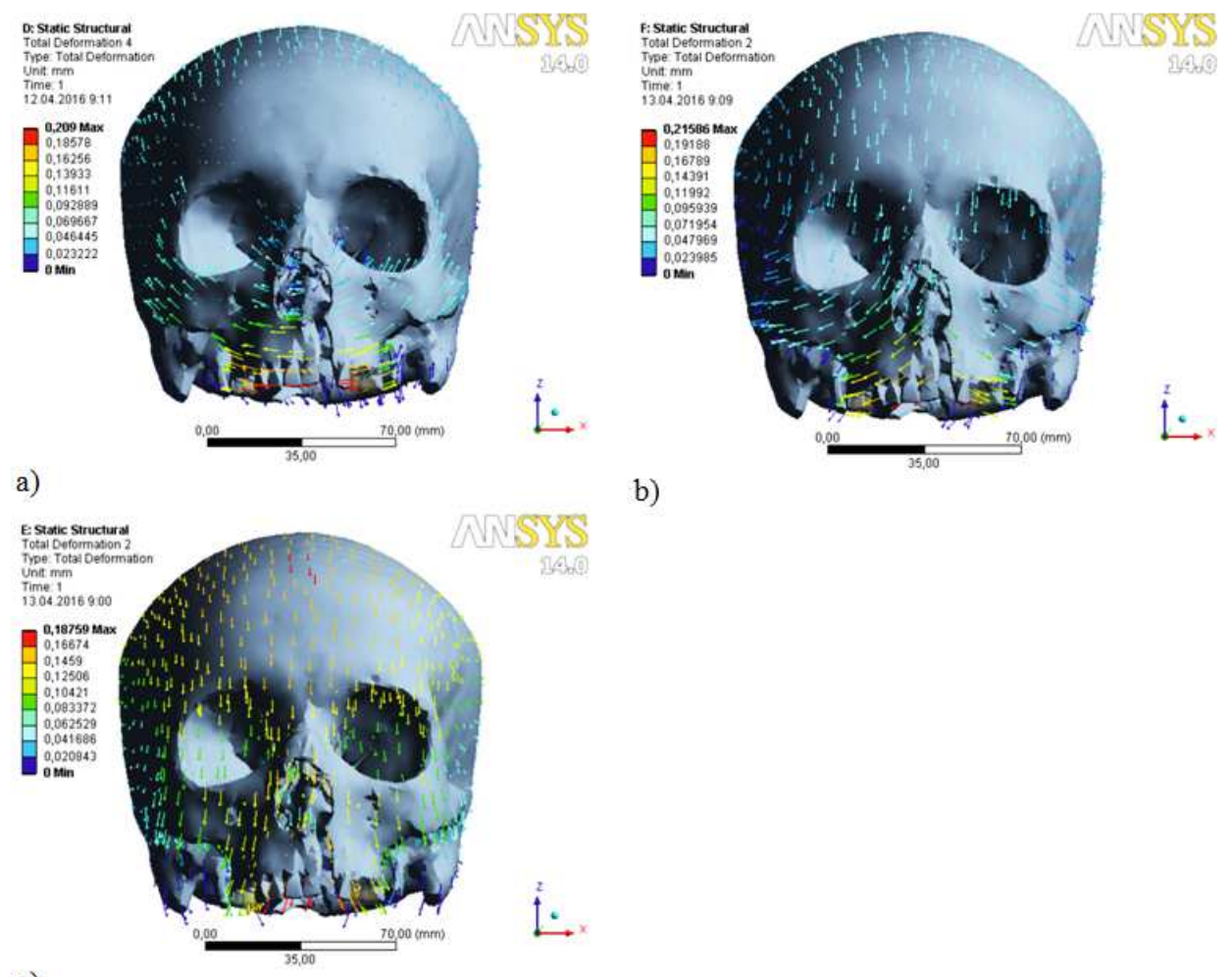

b)

c)

Fig. 8. Vector fields of total displacements for skull without palate cleft after application of: Model 1 (a), Model 2 (b) and Model 3 (c)

The displacement distributions that occur after application of Model 1 and 2 (Fig. 8b) are qualitatively almost identical to each other. The transversal dis- 
placements of the points on the skull run up to high enough displacements, compared to the values of transversal displacements which are observed after application of Model 1. From figure 8c it can be observed that after application of Model 3, the direction and magnitude of total displacement significantly changed as compared to Model 1. Mainly, the total displacements are directed along the $z$-axis. Thus, the front part of the skull moves down, and the rear part goes up, which leads to the rotation of the skull counterclockwise relative to the positive direction of the $z$-axis.

\section{Conclusions}

The highest stresses are observed in the alveolar processes of the upper jaw regardless of the location of the screw of the orthodontic appliance relative to the palate in the skull without cleft. Upon the displacement of the screw of the appliance from the occlusal plane to the palate, stresses are transferred from the upper jaw and its zygomatic processes to the frontal processes of the maxilla and cover the nasal cavity. The stress distributions after application of Model 1 and Model 2, in the base of the skull without clefts have significantly complicated form. The maximum values of the stresses decrease when the design of orthodontic appliance changes from Model 1 to Model 2, and the maximum stresses decrease in a nonlinear manner. The slight deviation of the screw of the appliance from the occlusal plane, corresponding to Model 3, in the skull without cleft does not lead to a qualitative change of the stress distribution. Total displacements of the points of the skull without cleft have the highest value, if the screw of the orthodontic appliance is slightly displaced from the occlusal plane to the palate. If the screw is located near the palate, mainly, the displacements of the points on the skull are directed vertically. The largest transversal displacements are observed in the skull after application of Model 2. The vector fields of the displacements show that after application of Models 2 and 3, the skull is rotated counterclockwise (when viewed from the positive direction of $x$-axis).

Stress distributions appear to be similar in the skull with unilateral palate cleft. The displacement of the screw of the orthodontic appliance to the palate in the skull with unilateral cleft leads to the decrease of the stresses in the region of the infraorbital foramen, zygomatic and frontal processes of the maxilla and in the zygomatic bone. At the same time, stresses in the zygomatic and frontal processes of the maxilla remain almost unchanged. The stress state remains practically unchanged in the base of the skull, when the screw of the orthodontic appliance is moved to the palate. Therefore, we can conclude that the stresses change qualitatively in the base of the skull, if the screw of the appliance is located directly near the palate. High stresses occur in the region of the mandibular processes of the upper jaw, both when using Model 1 as well as using Model 3. After application of Model 1 in the skull with cleft, two parts of the 
upper jaw turn relative to the horizontal axis (extending along the $y$-axis), located approximately in the region of the nasal aperture. Transversal displacements are the largest component of the total displacement. The displacement distributions that occur after application of Model 1 and 2 qualitatively almost coincide with each other. After application of Model 3, the direction and magnitude of total displacement significantly changed as compared to the appliance of Model 1. Mainly, the total displacements are directed along the vertical line. Thus, the front part of the skull moves down, and the rear part goes up, which leads to the rotation of the skull counterclockwise relative to the positive direction of the axis Oz. The skull with cleft is almost not rotated after application of Model 3 as compared to Models 1 and 2.

\section{References}

[1] Boryor A., Geiger M., Hohmann A., Wunderlich A., Sander Ch., Sander F.M., Sander F.G.: Stress distribution and displacement analysis during an intermaxillary disjunction - A three-dimensional FEM study of a human skull, J. Biomechanics, 41 (2008) 376-382.

[2] Bosiakov S., Vinokurova A., Dosta A.: Biomechanical effects of maxillary expansion in cross-bite patients during orthodontic treatment with Hyrax system, In: V. Mityushev, M. Ruzhansky (Eds.), Current Trends in Analysis and Its Applications. Birkhäuser Mathematics, XVI (2015) 793-802.

[3] Bosiakov S., Vinakurava A., Dosta A.: Deformations at the craniofacial complex depending on the HYRAX device design, ZN PRz Mechanika, 32 (2015) 5-15.

[4] Chaconas S.J., Caputo A.A.: Observation of orthopedic force distribution produced by maxillary orthodontic appliances, American J. Orthodontics, 82 (1982) 492-501.

[5] Chuah C., Mehra P.: Bilateral lingual anesthesia following surgically assisted rapid palatal expansion: report of a case, J. Oral Maxillofacial Surg.., 63 (2005) 416-418.

[6] Gautam P., Zhao L., Patel P.: Biomechanical response of the maxillofacial skeleton to transpalatal orthopedic force in a unilateral palatal cleft, Angle Orthodontist, 81 (2011) 503-509.

[7] Ghoneima A., Abdel-Fattah E., Hartsfield J., El-Bedwehi A., Kamel A., Kulaf K.: Effects of rapid maxillary expansion on the cranial and circummaxillary sutures, American J. Orthodontic Dentofacial Orthopedics, 140 (2011) 510-519.

[8] Goldenberg D.C., Goldenberg F.C., Alonso N., Gebrin E.S., Amaral Th. S., Scanavini M.A., Ferreira M.C.: Hyrax appliance opening and pattern of skeletal maxillary expansion after surgically assisted rapid palatal expansion: a computed tomography evaluation, Oral Surgery, Oral Medicine, Oral Pathology, Oral Radiology, and Endodontology, 106 (2008) 812-819.

[9] Han U.A., Kim Y., Park J.U. Three-dimensional finite element analysis of stress distribution and displacement of the maxilla following surgically assisted rapid maxillary expansion, J. Cranio-Maxillofacial Surgery, 37 (2009) 145-154. 
[10] Holberg C., Holberg N., Schwenzer K., Wichelhaus A., Rudzki-Janson I.: Biomechanical analysis of maxillary expansion in CLP patients, Angle Orthodontist, 77 (2007) 280-287.

[11] Isaacson R.J., Wood J.L., Ingram A.H.: Forces produced by rapid maxillary expansion, part I and II, Angle Orthodonics, 34 (1964) 256-270.

[12] Iseri H., Tekkaya, A.E., Öztan, Ö., Bilgiç, S.: Biomechanical effects of rapid maxillary expansion on the craniofacial skeleton, studied by the finite element method, European J. Orthodontics, 20 (1998) 347-356.

[13] Jafari A., Shetty K.S., Kumar M.: Study of stress distribution and displacement of various craniofacial structures following application of transverse orthopedic forces-a three dimensional FEM study, Angle Orthodontist, 73 (2003) 12-20.

[14] Lee H., Ting K., Nelson M., Sun N., Sung S.-J.: Maxillary expansion in customized finite element method models, American J. Orthodontics Dentofacial Orthopedics, 136 (2009) 367-374.

[15] Ludwig B., Baumgaertel S., Zorkun B., Bonitz L., Glasl B., Wilmes B., Lisson J.: Application of a new viscoelastic finite element method model and analysis of miniscrew-supported hybrid hyrax treatment, American J. Orthodontics Dentofacial Orthopedics, 143 (2013) 426-435.

[16] McGuinness N.J., McDonald J.P.: Changes in natural head position observed immediately and one year after rapid maxillary expansion, European J. Orthodontics, 28 (2006) 126-134.

[17] Pan X., Qian Yu., Yu J., Wang D., Tang Y., Shen G. Biomechanical effects of rapid palatal expansion on the craniofacial skeleton with cleft palate: a threedimensional finite element analysis, Cleft Palate Craniofacial J., 44 (2007)149-154.

[18] Provatidis C., Georgiopoulos B., Kotinas A., McDonald J.P.: On the FEM modeling of craniofacial changes during rapid maxillary expansion, Medical Eng. Physics, 29 (2007) 566-579.

[19] Romanyk D.L., Lagravere M.O., Toogood R.W., Major P.W., Carey J. P. Review of maxillary expansion appliance activation methods: engineering and clinical perspectives, J. Dental Biomechanics, 2010. DOI: 10.4061/2010/496906.

[20] Sander C., Huffmeier S., Sander F.M., Sander F.G.: Initial results regarding force exertion during rapid maxillary expansion in children, J. Orofacial Orthopedics, 67 (2006) 19-26.

[21] Tanne K., Sakuda M.: Biomechanical and clinical changes of the craniofacial complex from orthopedic maxillary protraction, Angle Orthodontist, 61 (1991) 145$-152$.

[22] Wang D., Cheng L., Wang Ch., Qian Yu., Pan X.: Biomechanical analysis of rapid maxillary expansion in the UCLP patient, Medical Eng. Physics, 31 (2009) 409$-417$. 


\section{WPEYW LOKALIZACJI ŚRUBY NA DOKRECCANIE NA ODPOWIEDŹ KOROWĄ PODCZAS SZYBKIEGO ROZSZERZANIA SIĘ SZCZĘKI}

\section{Streszczenie}

Do leczenia przekrwienia i niedoboru wymiarów przekroju poprzecznego szczęki u chorych z rozszczepem lub bez rozszczepu podniebienia i wargi stosowana jest szybka ekspandacja szczęki. Celem tego badania jest analiza naprężeń oraz przemieszczeń czaszki, z/bez jednostronnego rozszczepu, po zastosowaniu urządzenia ortodontycznego HYRAX. Uwzględniane są trzy różne konstrukcje przyrządu HYRAX z różnymi pozycjami śruby - w płaszczyźnie poziomej zgryzu, w pobliżu płaszczyzny poziomej okluzji i pod podniebieniem. Ustalono, że pozycja śruby w znaczący sposób wpływa na rozkłady przemieszczeń i naprężeń w czaszce z/bez jednostronnego rozszczepu podniebienia. W zależności od konstrukcji urządzenia ortodontycznego przemieszczane są połówki szczęki w płaszczyźnie poprzecznej lub cała czaszka jest całkowicie obracana w płaszczyźnie strzałkowej. Uzyskane wyniki mogą być wykorzystane do projektowania urządzeń ortodontycznych za pomocą śruby Hyrax, a także do planowania osteotomii podczas chirurgicznego wspomagania szybkiego rozszerzania się szczęki.

Słowa kluczowe: szybkie rozszerzenie szczęki, nienaruszona czaszka, rozszczep podniebienia, metoda elementów skończonych, urządzenie HYRAX, stan naprężenia-odkształcenia

DOI: $10.7862 / \mathrm{rm} .2017 .13$

Otrzymano/received: 12.01 .2017

Zaakceptowano/accepted: 17.03.2017 